DOI: https://doi.org/10.15688/lc.jvolsu.2017.3.9

UDC 340.12

LBC 67.0

\title{
THE ANALYSIS OF THE TARGET COMPONENT OF LAW INTERPRETATIVE ACTIVITIES
}

\author{
Evgeniy M. Terekhov \\ Balakovo Branch of Saratov State Academy of Law, Balakovo, Russian Federation
}

Introduction: law interpretative activities are an independent kind of legal activities, however, on a par with law-making and law enforcement they have not been investigated properly in the contemporary legal science. Law interpretative activities are to be regarded as a mechanism that is supported by having goals, an object, methods, subjects, principles, functions, varieties in their structure; therefore, in this work the author sets the task to explore their targets. Methods: the methodological framework for this study is a set of scientific methods, among which the main place is occupied by the methods of historicism, systematicity, analysis and the comparative law method. A particular attention is drawn to the static and dynamic methods in the consideration of law interpretative activities. Results: grounded in the work the author's position is based on the law and the authoritative scientists' opinions on the issue of establishing goals of law interpretative activities; the evolutionary nature of the process of interpreting the rules of law are taken into account. Conclusions: the study has identified a relevant goal of modern law interpretative activities. It is established that the fundamental goal of modern law interpretative activities is to discover the meaning of the rules of law, due to the economic, political, social, and cultural changes occurring in the society that are taken into consideration by the subjects of law interpretative activities when publishing the acts of the interpretation of the law. Therefore, it should be noted that the need for establishing the will of the legislator is evolutionarily behind the times and is not a real goal for law interpretative activities.

Key words: legal activities, law interpretative activities, interpretative act, interpretation of the law, interpretative practice, the Constitutional Court of the Russian Federation.

УДК 340.12

ББК 67.0

\section{АНАЛИЗ ЦЕЛЕВОЙ СОСТАВЛЯЮЩЕЙ ПРАВОИНТЕРПРЕТАЦИОННОЙ ДЕЯТЕЛЬНОСТИ}

\author{
Евгений Михайлович Терехов \\ Балаковский филиал Саратовской государственной юридической академии, \\ г. Балаково, Российская Федерация
}

\begin{abstract}
Введение: правоинтерпретационная деятельность выступает самостоятельным видом юридической деятельности, однако наравне с правотворческой и правоприменительной деятельностью должного исследования в современной юридической науке она не получила. Правоинтерпретационную деятельность следует рассматривать как механизм, что подтверждается наличием целей, объекта, методов, субъектов, принципов, функций, разновидностей в ее структуре, в связи с чем автором в настоящей работе поставлена задача исследовать ее целевые установки. Методы: методологическую основу данного исследования составляет совокупность методов научного познания, среди которых основное место занимают методы историзма, системности, анализа и сравнительно-правовой. Особое внимание обращается на статический и динамический методы в рассмотрении правоинтерпретационной деятельности. Результаты: обоснованная в работе авторская позиция опирается на законодательство и мнения авторитетных ученых по вопросу установления цели правоинтерпретационной деятельности, учитывается эволюционный характер процесса толкования норм права. Выводы: в результате проведенного исследования определена актуальная цель современной правоинтерпретационной деятельности. Установлено, что основополагающей целью современной правоинтерпретационной деятельности выступает раскрытие смысла норм права, что обусловлено экономически-
\end{abstract}


ми, политическими, социальными, культурными изменениями, происходящими в обществе, которые учитываются субъектами правоинтерпретационной деятельности при издании актов толкования права. Именно поэтому следует заметить, что необходимость установления воли законодателя эволюционно устарела и не является реальной целью для правоинтерпретационной деятельности.

Ключевые слова: юридическая деятельность, правоинтерпретационная деятельность, интерпретационный акт, толкование права, интерпретационная практика, Конституционный Суд РФ.

\section{Введение}

В условиях глобализации вслед за усложнением социально-экономической и политической жизни усложняется и правовая жизнь общества. В рамках последней особое место занимает юридическая деятельность, которая в самом общем виде подразделяется на правотворческую, правоинтерпретационную и правоприменительную. Среди всех ее разновидностей правоинтерпретационный вид в отечественной правовой науке исследован меньше других. Вместе с тем с уверенностью можно сказать, что без нее невозможно качественное и результативное правоприменение.

Постоянные дополнения и изменения в российском законодательстве, а также рост числа принимаемых нормативных правовых актов иногда приводят к усугублению неопределенности смысла отдельных положений закона - это ставит все острее вопрос толкования права.

\section{Основные трактовки правоинтерпретационной деятельности}

Полноценное исследование категории «правоинтерпретационная деятельность» невозможно себе представить без четкого понимания того, на достижение какой цели она ориентирована. Ситуация осложняется тем, что юридическая наука не содержит единого подхода к анализу цели правоинтерпретационной деятельности.

Е.В. Васьковский считал, что предназначение правоинтерпретационной деятельности кроется в раскрытии содержания нормы права, развитии ее смысла, выяснении воли законодателя [2, с. 29].

Ф. Регельсбергер приходит к выводу, что цель правоинтерпретационной деятельности состоит в раскрытии воли законодателя [11, с. 142].

По мнению С.А. Голунского и М.С. Строговича, предназначение правоинтерпретацион- ной деятельности заключается в разьяснении норм права [4, с. 240].

М.Н. Брагинский и В.В. Витрянский замечают, что в различные исторические времена правоинтерпретационная деятельность была направлена то на установление смысла закона, то на поиск воли законодателя, и наоборот [1, с. 215].

\section{Целевые установки} правоинтерпретационной деятельности

На сегодняшний день в юридической науке целесообразно выделить две ключевые точки зрения на проблему целевой установки правоинтерпретационной деятельности:

1. Выявление воли законодателя в тексте нормативного правового акта.

Воля законодателя может меняться, она не всегда соответствует смыслу закона, а иногда и вовсе связана со злоупотреблениями со стороны законодателя, поэтому вряд ли предназначение правоинтерпретационной деятельности кроется в установлении той самой воли.

Ю.Н. Тодыка обращает внимание на то, что воля законодателя многоаспектна: она может быть исторической, то есть смысл закона соответствует конкретным историческим условиям, в период которых был принят нормативный правовой акт, либо актуальной, когда закон принят несколько лет назад, а потребность в его толковании возникает до сих пор, применительно к современности [12, с. 48].

И.В. Михайловский замечал, что установление воли законодателя означает, что разъяснять смысл действующего нормативного правового акта должен только законотворец, который принял его, поскольку «никто лучше не может знать, что именно хотел он выразить в данном законе» [7, с. 414].

История развития законодательства знает немало случаев, когда разъяснения правотворцев пользовались не только приоритетом, но и абсолютной монополией, полностью или 


\section{ТЕОРИЯ И ПРАКТИКА ГОСУДАРСТВЕННО-ПРАВОВОГО РАЗВИТИЯ}

частично ограничивая иных субъектов правоинтерпретационной деятельности в издании актов толкования норм права.

При издании Corpus juris император Юстиниан предположил, что некоторые положения данного закона могут потребовать толкования и в случае возникновения такой необходимости суду запрещалось разьяснять спорные положения по своему внутреннему убеждению. Последний обязан был обратиться к самому императору, который лично решал, какой смысл нужно придавать отдельным правовым нормам [14, с. 256].

Во времена действия Свода законов в разделе Основных законов имелась оговорка, согласно которой «без доклада Императорскому Величеству никакое место, не исключая и высших правительств, не имеет права переменять в законе ни единой буквы и не допускать обманчивого непостоянства самопроизвольных толкований» [3, с. 129].

Возможно, такая позиция обусловливается нежеланием органов законодательной власти передавать часть полномочий по толкованию норм права органам судебной власти. В свою очередь субъектами правоинтерпретационной деятельности являются органы законодательной, исполнительной и судебной власти.

Судьи ежедневно разрешают споры между различными лицами на основе норм права и поэтому, как никто другой, знают, как следует толковать то или иное положение закона применительно к конкретной жизненной ситуации, поэтому законодатель никогда не сможет стать столь же квалифицированным правоведом, как судья. Юридическая деятельность не получит дальнейшего развития, если выявление воли законодателя связано с установлением монополии на толкование права одними субъектами правоинтерпретационной деятельности и ограничением в этом праве других. Именно поэтому выявление воли законодателя не может рассматриваться как основополагающая цель правоинтерпретационной деятельности.

2. Раскрытие смысла закона.

В статье 9 Устава гражданского судопроизводства было сказано, что «все судебные установления обязаны решать дела по точному разуму действующих законов, а в случае их неполноты, неясности, недостатка или противоречия основывать решения на общем смысле законов» [3, с. 362].

В.И. Ленин отмечал, что «каждое понятие находится в известном отношении, в известной связи со всеми остальными и содержание познания состоит в переходе понятий из одного в другое, в относительной противоположности между понятиями, тождестве противоположностей» $[6$, с. 179].

А.С. Пиголкин абсолютно справедливо замечал, что «необходимо затратить много усилий, чтобы создать для себя ясное и в то же время глубокое представление о правовой норме, даже если по первому впечатлению ее смысл ясен» $[9$, с. 98]. Нет ничего более неоднозначного, чем уверенность в ясности нормы права, возникающая при первом знакомстве с ней.

Норму права следует толковать с учетом исторических, социальных, экономических, культурных изменений, произошедших со времени принятия нормативного правового акта до настоящего времени. Норма права должна быть наделена юридическим смыслом, который можно корректировать в направлении, необходимом правовому регулированию и юридической деятельности, однако делать это могут лишь субъекты правоинтерпретационной деятельности, в первую очередь органы судебной власти, и никто другой.

В.Д. Зорькин, подводя итоги правоинтерпретационной деятельности на торжественном заседании, посвященном двадцатилетию Конституционного Суда РФ, заявил, что «характер интерпретации Судом положений Конституции не может слепо следовать только букве Основного закона. Конституция - не неприкасаемый манускрипт, предназначенный для сдувания пыли. Ее реальная действенность зависит от того, насколько разумно и обоснованно Конституционный Суд в своих решениях учитывает и объективирует баланс конституционных ценностей, определяемый конкретными обстоятельствами жизни общества и государства в конкретный исторический отрезок времени» [5]. Тем самым председатель Конституционного Суда РФ обратил внимание не на формальное толкование буквы закона посредством установления воли законодателя, а на поиск смысла нормы права, анализируя экономические, социальные, культурные и иные изменения, происходящие в обществе. 
Не так давно предметом рассмотрения Конституционного Суда РФ явилась проверка конституционности не вступившего в силу международного договора между Российской Федерацией и Республикой Крым о принятии в состав РФ Республики Крым и образовании в составе России новых субъектов.

Конституционный Суд РФ разъяснил, что указанный договор не противоречит Конституции РФ с позиции принципа разделения властей и разграничения компетенции между федеральными органами государственной власти, соответствует всем требованиям действующего законодательства, предъявляемым к такому виду документов [10]. Суд в данном случае осуществил правоинтерпретационную деятельность:

- с учетом исторического критерия Крымская область территориально входила в состав РСФСР, однако 9 марта 1954 г. была передана в состав Украинской Советской Социалистической Республики [13];

- с учетом социального и культурного критерия - подавляющее большинство лиц, проживающих на территории Республики Крым, являются русскоговорящими гражданами, численность которых на 2014 г. составляла $65,2 \%$ [8].

Выявление воли законодателя в тексте нормативного правового акта не может выступать целью правоинтерпретационной деятельности, поскольку это означало бы необходимость исследования условий, при которых был принят закон, установления хода мысли законодателя и т. д. Важно понимать, что принятие закона - очень сложный процесс, в котором задействовано большое количество творцов права из разных фракций и комитетов, носящий коллективный характер. При обсуждении закона в чтениях каждый из депутатов может вкладывать в его текст свой собственный смысл. Кроме того, можно выделить волю законодателя в процессе разработки законопроекта, его обсуждения, внесения необходимых изменений.

\section{Выводы}

Таким образом, все более очевидным становится тот факт, что основополагающей целью современной правоинтерпретационной деятельности выступает раскрытие смысла норм права. На данный процесс оказывают значение экономические, политические, социальные, культурные изменения, происходящие в обществе, которые учитываются субъектами правоинтерпретационной деятельности при издании актов толкования права. Именно поэтому следует заметить, что необходимость установления воли законодателя эволюционно устарела и не является актуальной для современной правоинтерпретационной деятельности.

\section{СПИСОК ЛИТЕРАТУРЫ}

1. Брагинский М. Н. Договорное право / М. Н. Брагинский, В. В. Витрянский. - М. : Статут, 1997. $-682 \mathrm{c}$.

2. Васьковский, Е. В. Руководство к толкованию и применению законов / Е. В. Васьковский. М. : Изд. Бр. Башмаковых, 1913. - 152 с.

3. Васьковский, Е. В. Цивилистическая методология. Учение о толковании и применении гражданских законов / Е. В. Васьковский. - М. : Центр ЮрИнфоР, 2002.- 508 с.

4. Голунский, С. А. Теория государства и права / С. А. Голунский, М. С. Строгович. - М. : Юридическое изд-во НКЮ СССР, 1940. - 304 с.

5. Зорькин, В. Д. Юбилей КС. Выступление на торжественном заседании, посвященном двадцатилетию Конституционного Суда РФ / В. Д. Зорькин // Российская газета. $-2011 .-27$ окт.

6. Ленин, В. И. Полн. собр. соч. Т. 29 / В. И. Ленин. - М. : Госполитиздат, 1969. - 781 с.

7. Михайловский, И. В. Очерки философии права. Т. 1 / И. В. Михайловский. - Томск : Издание книжного магазина В. М. Посохина, 1914. -632 с.

8. Население Крыма и Севастополя: численность, национальный состав. - Электрон. текстовые дан. - Режим доступа: http://www.statdata.ru (дата обращения: 15.03.2017). - Загл. с экрана.

9. Пиголкин, А. С. Толкование нормативных актов в СССР / А. С. Пиголкин. - М. : Госюриздат, 1962. $-166 \mathrm{c}$.

10. Постановление Конституционного Суда РФ «По делу о проверке конституционности не вступившего в силу международного договора между Российской Федерацией и Республикой Крым о принятии в Российскую Федерацию Республики Крым и образовании в составе Российской Федерации новых субъектов» от 19 марта 2014 г. № 6-П // Российская газета. - 2014. - 20 марта.

11. Регельсбергер, Ф. Общее учение о праве / Ф. Регельсбергер. - М. : Изд-во И.Д. Сытина, 1897. $296 \mathrm{c}$. 
12. Тодыка, Ю. Н. Толкование Конституции и законов Украины: теория и практика / Ю. Н. Тодыка. - Харьков : Факт, 2003. - 328 с.

13. Указ Президиума Верховного Совета СССР «О передаче Крымской области из состава РСФСР в состав УССР» от 19 февр. 1954 г. // Ведомости Верховного Совета СССР. - 1954. - 9 марта.

14. Черткова, Ю. В. Проблемы судебного правотворчества в истории и современности / Ю. В. Черткова // Ученые записки Крымского федерального университета. Серия «Юридические науки». - 2015. № 1. - C. 255-261.

\section{REFERENCES}

1. Braginskiy M.N., Vitryanskiy V.V. Dogovornoe pravo [Contract Law]. Moscow, Statut Publ., 1997. 682 p.

2. Vaskovskiy E.V. Rukovodstvo k tolkovaniyu $i$ primeneniyu zakonov [Guide to the Interpretation and Application of Laws]. Moscow, Izd. Br. Bashmakovykh, 1913. $152 \mathrm{p}$.

3. VaskovskiyE.V. Tsivilisticheskaya metodologiya. Uchenie o tolkovanii i primenenii grazhdanskikh zakonov [Civilistic Methodology. The Doctrine on Interpretation and Application of Civil Laws]. Moscow, Tsentr YurInfoR Publ., 2002.508 p.

4. Golunskiy S.A., Strogovich M.S. Teoriya gosudarstva i prava [Theory of State and Law]. Moscow, Yurid. izd-vo NKYu SSSR, 1940. 304 p.

5. Zorkin V.D. Yubiley KS. Vystuplenie na torzhestvennom zasedanii, posvyashchennom dvadtsatiletiyu Konstitutsionnogo Suda RF [Anniversary of the Constitutional Court. Speech at the Ceremonial Meeting Dedicated to the $20^{\text {th }}$ Anniversary of the Constitutional Court of the Russian Federation]. Rossiyskaya gazeta, 2011, Oct. 27.

6. Lenin V.I. Polnoe sobranie sochineniy. T. 29 [Complete Collection of Writings. Vol. 29]. Moscow, Gospolitizdat Publ., 1969. 781 p.

7. Mikhaylovskiy I.V. Ocherkifilosofii prava. T. 1 [Essays on the Philosophy of Law]. Tomsk, Izdanie knizhnogo magazina V. M. Posokhina, 1914. 632 p.
8. Naselenie Kryma i Sevastopolya: chislennost, natsionalnyy sostav [Population of Crimea and Sevastopol: Size, Ethnic Composition]. URL: www.statdata.ru. (accessed March 15, 2017).

9. Pigolkin A.S. Tolkovanie normativnykh aktov $v$ SSSR [Interpretation of Regulatory Acts in the USSR]. Moscow, Gosyurizdat Publ., 1962. 166 p.

10. Postanovlenie Konstitutsionnogo Suda RF «Po delu o proverke konstitutsionnosti ne vstupivshego v silu mezhdunarodnogo dogovora mezhdu Rossiyskoy Federatsiey i Respublikoy Krym o prinyatii v Rossiyskuyu Federatsiyu Respubliki Krym i obrazovanii v sostave Rossiyskoy Federatsii novykh subyektov» ot 19 marta 2014 g. № 6-P [Decision of the Constitutional Court of the Russian Federation "On the Case on Verification of the Constitutionality of a Non-Enacted International Treaty between the Russian Federation and the Republic of Crimea on Admission of the Republic of Crimea to the Russian Federation and the Formation of New Subjects within the Russian Federation" of March 19, 2014 no. 6-P]. Rossiyskaya gazeta, 2014, March 20.

11. Regelsberger F. Obshchee uchenie o prave [The General Doctrine of Law]. Moscow, Izd-vo I.D. Sytina, 1897. 296 p.

12. Todyka Yu.N. Tolkovanie Konstitutsii $i$ zakonov Ukrainy: teoriya i praktika [Interpretation of the Constitution and Laws of Ukraine: Theory and Practice]. Kharkov, Fakt Publ., 2003. 328 p.

13. Ukaz Prezidiuma Verkhovnogo Soveta SSSR «O peredache Krymskoy oblasti iz sostava RSFSR v sostav USSR» ot 19 fevr. 1954 g. [Decree of the Presidium of the Supreme Council of the USSR "On the Transfer of the Crimean Region from the RSFSR to the Ukrainian SSR" of February 19, 1954]. Vedomosti Verkhovnogo Soveta SSSR, 1954, March 9.

14. Chertkova Yu.V. Problemy sudebnogo pravotvorchestva $\mathrm{v}$ istorii i sovremennosti [Problems of Judicial Lawmaking in History and Modernity]. Uchenye zapiski Krymskogo federalnogo universiteta. Seriya «Yuridicheskie nauki», 2015, no. 1, pp. 255-261.

\section{Information about the Author}

Evgeniy M. Terekhov, Candidate of Juridical Sciences, Associate Professor, Department of State and Law Disciplines, Balakovo Branch of Saratov State Academy of Law, Krasnaya Zvezda St., 8/1, 413865 Balakovo, Russian Federation, terehov1989@yandex.ru.

\section{Информация об авторе}

Евгений Михайлович Терехов, кандидат юридических наук, доцент кафедры государственно-правовых дисциплин, Балаковский филиал Саратовской государственной юридической академии, ул. Красная Звезда, 8/1, 413865 г. Балаково, Российская Федерация, terehov1989@yandex.ru. 